AGRICULTURE AND BIOLOGY JOURNAL OF NORTH AMERICA

ISSN Print: 2151-7517, ISSN Online: 2151-7525, doi:10.5251/abjna.2012.3.12.481.485

(C) 2012, ScienceHuß, http://www.scihub.org/ABJNA

\title{
Effect of extracts from leaves, bark and root of Azadiratcha indica $L$ on the vegetative growth of Colletrichum gloeosporoides :field soft rot pathogen of soursop (Annona muricata $L$ ) fruit
}

\author{
Nweke, C.N and Ibiam, O. F. A \\ Department of Applied Biology, Faculty of Biological Sciences, Ebonyi State University, \\ Abakaliki. Nigeria \\ ABSTRACT \\ The effect of the extract from leaves, bark and root of neem plant (Azadiratcha indica L)on the \\ vegetative growth of Colletotrichum gloeosporoides :soft rot field pathogen of soursop (Annona \\ muricata $L$ ) fruits was investigated. The result obtained showed that all the parts of the test plant \\ screened significantly $(p<0.05)$ inhibited the growth of the fungal isolate.The root extract of the \\ test plant gave the highest level of inhibition from the treatment concentration of $300 \mathrm{mg} / \mathrm{ml}$, while \\ the leaf extract was the least. The leaf and the bark extracts completely inhibited the mycelial \\ growth from treatment concentration of $400 \mathrm{mg} / \mathrm{ml}$. It was concluded that plant extracts, \\ particularly the one used in this study could offer a safe alternative for use as a botanical \\ fungicide.
}

Key words: Extracts, vegetative growth ,soft rot, pathogen, fruit

\section{INTRODUCTION}

Although no report has been given on the use of plant extracts for the control of the soft-rot diseases of Annona muricata, several extracts from plants have been used to control similar post-harvest pathogens in other crops. According to Nwachukwu and Umechuruba (2001), leaf extracts of neem were shown to be efficacious on major seed-borne of African yam bean seeds and on seed germination and seedling emergence. Ejale and Abdullah (2004), pointed out that the dried leaf powder of neem was used to control the post-harvest rot of tomato. On the contrary, Oluma and Elaigwe (2006) observed that extracts of $A$. indica had no inbibitory effect on the mycelial growth and sclerotial formation of Macrophomina phaseolina. Premlatha (1982) also gave similar report on the ineffectiveness of neem extract against Rhizoctonia solani.

The active principles present in plants are influenced by many factors, which include the age of plant, extracting solvent, method of extraction and time of harvesting plant materials (Okigbo and Ogbonnaya, 2006). According to Kurucheve et al (1997), the presence of inhibitors to the fungitoxic principle may contribute to differences observed in the anti-fungal activity of some plant extracts.

Okigbo and Ogbonnaya (2006), stated that the use of extracts from plants for plant disease management is economically viable and poses little environmental risk, and the plants are available to farmers in Nigeria that do not have ready access to other synthetic fungicides.

Biu et al (2009), in his investigation observed the presence of anti-nutrients like saponins, tannins, glycosides, alkaloids, terpenes and flavenoids in the aqueous extracts of the leaves of Azadirachta indica (neem).According to Benneth and Wallsgrove (1994) and Grayer and Harbourne (1994), a large number of constitutive plant compounds have been reported to have anti-fungal activity, and well known examples include glycosides, phenols, saponins and glucosinolates. Osbourn(1996), stated that many saponins exhibit potent anti-fungal activity, and are often present in relatively high levels in healthy plants, and as a result have been implicated as determinants of a plant's resistance to fungal attack. Price et al (1987); Fenwick et al (1992) and Hostettman and Marston (1995), stated that a number of other properties associated with saponin compounds included piscidal, insecticidal and molloscicidal activity; allelopathic action; and antinutritional effects. Umar et al (2002); Makein et al (2007) and Wikipedia (2007), pointed out that Azadirachtin extracts from the seeds, leaves and bark of the neem tree has been reported to have strong biological activities against insect pest, but with very low toxicity to mammals and the environment, generally.

Several benefits are derived from soursop plants, ranging from medicinal to mineral supplement, and 
the fruits of this plant are usually devastated by postharvest fungal pathogens, one of which investigated is Colletotrichum gloeosporoides. This work is aimed at using the extracts from the leaves, roots and bark of Azadiratcha indica for the control of the vegetative growth of this pathogen in vitro. The use of this plant is informed by the efficacy of extracts from some parts of the plant on some pathogenic fungi, and the need to use fungitoxic extracts from plants that are environmental friendly, and are easily available to farmers.

\section{MATERIALS AND METHODS}

The selected plant was Azadirachta indica (neem). The plant parts used were the leaves, bark and the roots. They were obtained from Ukawu in Onicha Local Government Area of Ebonyi State, and identified in the Department of Applied Biology, Ebonyi State University, Abakaliki. Nigeria

Preparation of Plant Extract: Fresh mature leaves, bark and the roots of the test plant were collected, washed separately with several changes of sterile distilled water and air dried for seven days. They were blended with sterile blender and sieved with a fine sterile cheese clothes to obtain some fine powder. A cold water extract of the blended leaves, bark and roots of the test plant were prepared separately by adding 1,2,3,4 and $5 \mathrm{~g}$ of the different parts of the powdered test plants separately to $250 \mathrm{mls}$ conical flask containing $10 \mathrm{mls}$ of cold sterile distilled water and allowing them to settle for $24 \mathrm{hrs}$. The resulting solutions were filtered through sterile cheese cloth, which then gave the plant extract concentrations of $100 \mathrm{mg} / \mathrm{m1}, 200 \mathrm{mg} / \mathrm{m} 1,300 \mathrm{mg} /$ $\mathrm{m} 1,400 \mathrm{mg} / \mathrm{m} 1$ and $500 \mathrm{mg} / \mathrm{m} 1$ respectively. The plant extracts were put in sterile McCartney bottles and labeled accordingly, while the research lasted. All preparations were done in replicates of three each. Sterile distilled water was used as control.

Method of inoculation: $2 \mathrm{mls}$ of the different concentrations of the plant extracts prepared were separately dispensed into McCartney bottles containing $18 \mathrm{mls}$ of soursop fruit dextrose broth. Each of the bottles containing the extract concentrations and the nutrient broth was inoculated with $5 \mathrm{~mm}$ disc of five-day old culture of the test fungus and incubated at $25 \pm 2^{\circ} \mathrm{C}$ for a period of seven days. The bottles were arranged in replicates of 3 for each of the extract concentrations and for each day till the seven days, giving a total of 126 bottles for each plant part used. The control contained only sterile distilled water.
Determination of fungal inhibition: The mycelia were harvested daily by filtrating with sterile cheese cloth and oven drying the mycelia overnight at $80^{\circ} \mathrm{C}$ till constant weight was obtained. The average of the 3 replicates were obtained and recorded. The percentage inhibition was calculated using the formula: 1nhibition $=100(\mathrm{C}-\mathrm{T}) / \mathrm{C}$

\section{Where $\mathrm{C}=$ growth of control $\mathrm{T}=$ growth of treatment \\ RESULTS AND DISCUSSION}

Results in Tables 1 and 2 show that all the different parts (leaf, bark and root) of the test plant used exhibited some anti-fungal activity when compared with the control. With the leaf extracts of Azadirachta Indica, fungal growth occurred on the third day after inoculation at the treatment concentrations of $100 \mathrm{mg} / \mathrm{ml}, 200 \mathrm{mg} / \mathrm{ml}$ and $300 \mathrm{mg} / \mathrm{ml}$ and the same completely inhibited the vegetative growth of the fungus at treatment concentrations of $400 \mathrm{mg} / \mathrm{ml}$ and $500 \mathrm{mg} / \mathrm{ml}$. The vegetative growth of the pathogen appeared on the fourth day after inoculation with the bark extracts of $A$ .Indica at concentrations of $100 \mathrm{mg} / \mathrm{ml}, 200 \mathrm{mg} / \mathrm{ml}$ and $300, \mathrm{~g} / \mathrm{ml}$. However, at treatment concentrations of $400 \mathrm{mg} / \mathrm{ml}$ and $500 \mathrm{mg} / \mathrm{ml}$, there was complete inhibition of the vegetative growth of the fungal pathogen. Results also show that the root extracts of the test plant used in this study completely inhibited the growth of the fungal pathogen at concentrations of $300 \mathrm{mg} / \mathrm{ml}, 400 \mathrm{mg} / \mathrm{ml}$ and $500 \mathrm{mg} / \mathrm{ml}$. However, at treatment concentrations of $100 \mathrm{mg} / \mathrm{ml}$ and $200 \mathrm{mg} / \mathrm{ml}$, the growth of the fungal mycelium appeared on the fourth and fifth day respectively. Analysis of variance (ANOVA) carried out at $95 \%$ probability showed that the anti - fungal activities of the leaf, bark and the root extracts of $A$. Indica used in this study were significant $(P<0.05)$.

The anti-fungal activities of the leaf, bark and root extracts of $A$ indica_against the fungal_isolate as shown in (Table 1), revealed that root extracts gave the highest level of inhibition, and the leaf extracts the least. The leaf and bark extracts gave complete inhibition of the mycelial growth at treatment concentrations of $400 \mathrm{mg} / \mathrm{ml}$ and above, while the root extracts completely inhibited the mycelial growth at concentrations of $300 \mathrm{mg} / \mathrm{ml}$ and above. The various parts of the test plant used were fungitoxic at all concentrations when compared with the control. The antifungal activities of the leaf bark and root extracts of the test plant increased with corresponding increase in the treatment concentrations. It could, therefore, be suggested that using higher concentrations of $500 \mathrm{mg} / \mathrm{ml}$ could be more promising in the effective control of the fungal soft-rot pathogen of the fruits by using them as fungicidal spray in the field to eliminate or reduce the fungal pathogens. 
Agric. Biol. J. N. Am., 2012, 3(12): 481-485

Table 1: Mean percentage (\%) inhibition of Mycelial growth of the fungal pathogen harvested from the soursop fruit dextrose-Broth by the leaf, bark and root extracts of $A$.indica

\begin{tabular}{|c|c|c|c|c|c|c|c|c|c|c|c|c|c|c|c|c|c|c|c|c|c|}
\hline & & & & DAY I & & & DAY III & & & DAY IV & & & DAY V & & & DAY VI & & & DAY VII & & \\
\hline $\begin{array}{l}\text { Concentra } \\
\text { tion } \\
(\mathrm{mg} / \mathrm{ml})\end{array}$ & $\mathrm{L}$ & B & $\mathbf{R}$ & $\mathrm{L}$ & B & $\mathbf{R}$ & $\mathrm{L}$ & B & $\mathbf{R}$ & $\mathrm{L}$ & B & $\mathbf{R}$ & $\mathrm{L}$ & B & $\mathbf{R}$ & $\mathrm{L}$ & B & $\mathbf{R}$ & L & B & $\mathbf{R}$ \\
\hline $100 \mathrm{mg} / \mathrm{ml}$ & - & - & - & $100 \pm 0$ & $100 \pm 0$ & $100 \pm 0$ & $60 \pm 0.5$ & 100 & 100 & $56.90 \pm 1.2$ & $81.54 \pm 0.1$ & $83.10 \pm 1.0$ & $53.16 \pm 2.3$ & $77.22 \pm 0.6$ & $79.70 \pm 0.6$ & $53.10 \pm 0.01$ & $74.10 \pm 2.7$ & $77.80 \pm 0.31$ & $50 \pm 1.5$ & $7391 \pm 0.05$ & $76.10 \pm 1.7$ \\
\hline $200 \mathrm{mg} / \mathrm{ml}$ & & & & $100 \pm 0$ & $100 \pm 0$ & $100 \pm 0$ & $88.33 \pm 1.0$ & 100 & 100 & $56.92 \pm 1.8$ & $84.62+2.6$ & 100 & $53.20 \pm 0.21$ & $83.54 \pm 0.28$ & $88.61 \pm 0.8$ & $53.10 \pm 2.5$ & $82.72 \pm 2.3$ & $87.65 \pm 0.5$ & $52.20 \pm 1.3$ & $82.61 \pm 0.01$ & $87.00 \pm 0.3$ \\
\hline $300 \mathrm{mg} / \mathrm{ml}$ & - & - & - & $100 \pm 0$ & $100 \pm 0$ & $100 \pm 0$ & $95+1.6$ & 100 & 100 & $87.70 \pm 0.2$ & $96.92 \pm 3.2$ & 100 & $86.10 \pm 0.5$ & $92.41 \pm 0.2$ & 100 & $85.20 \pm 0.02$ & $91.36 \pm 0.67$ & 100 & $84.79 \pm 2.4$ & $90.22 \pm 0.2$ & 100 \\
\hline $400 \mathrm{mg} / \mathrm{ml}$ & & & & $100 \pm 0$ & $100 \pm 0$ & $100 \pm 0$ & $100 \pm 0$ & $100 \pm 0$ & $100 \pm 0$ & $100 \pm 0$ & $100 \pm 0$ & $100 \pm 0$ & $100 \pm 0$ & $100 \pm 0$ & $100 \pm 0$ & $100 \pm 0$ & $100 \pm 0$ & $100 \pm 0$ & $100 \pm 0$ & $100 \pm 0$ & $100 \pm 0$ \\
\hline $500 \mathrm{mg} / \mathrm{ml}$ & & & & $100 \pm 0$ & $100 \pm 0$ & $100 \pm 0$ & $100 \pm 0$ & $100 \pm 0$ & $100 \pm 0$ & $100 \pm 0$ & $100 \pm 0$ & $100 \pm 0$ & $100 \pm 0$ & $100 \pm 0$ & $100 \pm 0$ & $100 \pm 0$ & $100 \pm 0$ & $100 \pm 0$ & $100 \pm 0$ & $100 \pm 0$ & $100 \pm 0$ \\
\hline Control & - & - & - & - & - & - & - & & & - & - & - & - & - & - & - & - & - & - & - & - \\
\hline
\end{tabular}

$\mathrm{L}=$ leaf, $\mathrm{B}=$ Bark, $\mathrm{R}=$ Root.

No inhibition

1-49 - Fair inhibition

50-59 - Moderate inhibition

60-99 - High inhibition

$100 \quad$ - Complete inhibition

Table 2: Mean percentage (\%) Mycelial ash weight of fungal pathogen harvested from the media treated with the leaf, bark and root extracts of $A$ indica

\begin{tabular}{|c|c|c|c|c|c|c|c|c|c|c|c|c|c|c|c|c|c|c|c|c|c|}
\hline & DA & Y1 & & DA & & & DAY III & & & DAY IV & & & DAY V & & & DAY VI & & & DAY VII & & \\
\hline $\begin{array}{l}\text { Conc. } \\
\text { (mg/ml) }\end{array}$ & $\mathbf{L}$ & B & $\mathbf{R}$ & $\mathrm{L}$ & B & $\mathbf{R}$ & $\mathrm{L}$ & B & $\mathbf{R}$ & $\mathrm{L}$ & B & $\mathbf{R}$ & $\mathrm{L}$ & B & $\mathbf{R}$ & $\mathrm{L}$ & B & $\mathbf{R}$ & $L$ & B & $\mathbf{R}$ \\
\hline $100 \mathrm{mg} / \mathrm{ml}$ & & & & & & & $40 \pm 1.8$ & - & - & $43.1 \pm 2.7$ & $13.46 \pm 2.30$ & $16.90 \pm 1.81$ & $47 \pm 3.19$ & $22.78 \pm 1.06$ & $20.30 \pm 1.50$ & $47 \pm 4.47$ & $25.93 \pm 1.64$ & $22.22 \pm .83$ & $50 \pm 2.16$ & $26.10 \pm 2.17$ & $23.46 \pm 0.53$ \\
\hline $200 \mathrm{mg} / \mathrm{ml}$ & & & & & & & $11.67 \pm 3.9$ & - & - & $30.77 \pm 2.67$ & $15.38 \pm 0.89$ & - & $32.91 \pm 1.12$ & $16.46 \pm 1.10$ & $11.40 \pm 0.94$ & $34.57 \pm 2.75$ & $17.28 \pm 0.14$ & $12.35 \pm .10$ & $47.83 \pm 4.35$ & $17.39 \pm 2.16$ & $13.0 \pm 1.43$ \\
\hline $300 \mathrm{mg} / \mathrm{ml}$ & & & & & & & $5 \pm 0.0$ & - & - & $12.31 \pm 1.70$ & $3.10 \pm 0.11$ & - & $13.92 \pm 0.00$ & $7.60 \pm 1.18$ & - & $14.80 \pm 1.77$ & $8.64 \pm 0.1$ & - & $15.22 \pm 0.72$ & $8.70 \pm 1.10$ & \\
\hline $400 \mathrm{mg} / \mathrm{ml}$ & - & - & & . & & - & & & & & & & & & & & & & & - & \\
\hline $500 \mathrm{mg} / \mathrm{ml}$ & - & - & - & - & - & - & 0.00 & - & - & - & 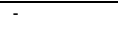 & - & - & - & - & - & - & - & - & - & - \\
\hline Control & - & & & $\begin{array}{l}10 \\
0\end{array}$ & 100 & 100 & 100 & 100 & 100 & 100 & 100 & 100 & 100 & 100 & 100 & 100 & 100 & 100 & 100 & 100 & 100 \\
\hline
\end{tabular}

$\mathrm{L}=$ leaf, $\mathrm{B}=$ Bark, $\mathrm{R}=$ Root 
Oluma and Elaigwe (2006), had reported that extracts of Azadiratcha. Indica had no inhibitory effect on the growth of $M$. phaseolina. Premlatha (1982), in his investigation also made similar report that neem plant was ineffective against Rhizoctonia solani. These findings disagree with the present investigation in view of the observed antifungal activities of the various parts of neem plant used in the present study. The report of Nwachukwu and Umechuruba (2001) that the extract of neem was observed to be promising for protecting African yam, bean seeds against major seed-borne fungi agrees with the present investigation. However these investigations indicate that neem extracts may be selective in its antifungal activity. It could also be suggested that experimental errors in extraction components and sterilization procedures as well as variation in plant composition arising from regional differences might have contributed to the disparities in these reports. Kurucheve et al (1997), suggested that the presence of inhibitors to the fungitoxic principle might be contributory to the differences observed in the antifungal activity of some plant extracts.

Analysis of variance at $95 \%$ showed that all the parts (leaf, bark and root) of the test plant used in this study significantly $(P<0.05)$ inhibited the growth of the fungal organism The observed antifungal activities of neem plant in the present study indicates that neem plant extracts could hold great promise in the effective preservation of ripe fruits of soursop and other tropical fruits from degradative activities of fungal soft-rot pathogens. Although no phytochemical screening of the various parts of the neem plant was carried out in this work, Biu et al (2009), observed the presence of saponins, tannins, glycosides, alkaloids, terpenes and flavenoids in aqueous leaf extracts of neem. Bennett and Wallsgrove (1994); Grayer and Harbourne (1994), observed that glycosides and saponins have antifungal activity. Osbourn (1996), observed that many saponins exhibit potent antifungal activity and are often present in relatively high levels in healthy plants and as a result have been implicated as determinants of a plant's resistance to fungal attack. This suggests that these phytochemical components might have been responsible for the observed antifungal properties of the test plant used in the present study.

\section{CONCLUSION AND RECOMMENDATION:}

The present study was carried out to the antifungal activities of the cold water extracts of leaf, bark and the root of neem plant ( Azadiratch indica against the isolated fungal pathogen. The damaging activities by plant pathogens could be reduced by the use of plant extracts. Plant extracts, particularly, the one used in this study offer a potentially simple environmentally safe alternative for use as botanical fungicides, and could be exploited for the effective management of pre-harvest diseases of tropical fruits. The added advantages to these are that plant extracts are cheaper and non-toxic to man if the appropriate concentrations are used. It is, therefore, recommended that aqueous extracts of the various parts of the test plant used in this study be used by farmers and fruit handlers at such concentration as $500 \mathrm{mg} / \mathrm{ml}$ to treat fruits before storage in order to check the soft-rot diseases of fruits or rather maximize their marketing or storage periods.

\section{REFERENCES}

Bennett, R. N. and Wallsgrove, R. M. (1994). Secondary Metabolites in plant defence mechanisms. New_Phytol. 127: 617-633.

Biu, A.A., Yusuf, S. D. and Rabo, J.S. (2009). Phytochemical screening of Azadirachta indica (Neem). Bioscience Research Communications 21: 281-283.

Ejale, A. U. and Abdullah, H. O. (2004). Preservation of ripe tomato fruits with dried leaf powder of Neem. Nigerian Journal of Applied Science. 22: 344-370.

Fenwick, G. R., Price, K. R., Tsukamota, C. and Okubo, K. (1992). Saponins. In: Toxic substances in crop plants. Duffus, C. M. and

Duffus, J. H. (eds). Royal Society of Chemistry, Cambridge, UK. Pp 285-327.

Grayer, R. J. and Harbourn, J. J. (1994). A Survey of antifungal compounds from higher plants. Phytochemistry. 37: 19-42.

Hostettman, K. A. and Marston, A. (1995). Saponins, chemistry and pharmacology of natural products. $2^{\text {nd }}$ ed. Cambridge University Press. 286pp.

Kurucheve, V. and Padmavathi, R. (1997). Fungitoxicity of selected plant products against Pythium aphanidermatum. Indian phytopathology. 50: 529-535.

Makein, H. K., Maikai, V.A. and Nok, J. A. (2007). Effect of topical application of neem seed extract on sheep infested with Amblyomma variegatum. African Journal of Biotechnology. 6(20): 2324-2327.

Nwachukwu, E. O. and Umechuruba, C. I. (2001). Antifungal activities of some leave extracts on seedborne fungi of African yam bean seeds. Journal of Applied and Natural Sciences 1: 29-31.

Okigbo, R. N. and Ogbonnaya, U. O. (2006). Antifgunal effects of two tropical plant extracts (Ociumu 
Agric. Biol. J. N. Am., 2012, 3(12): 481-485

gratissiumum and Afromomum melequeta) on postharvest yam (Dioscorea spp.) rot. African Journal of Biotechnology. 5: 5727-731.

Oluma, H.O.A. and Elaigwe, M. (2006) Antifungal activity of extracts of some medicinal plants against Macrophomina phaseolina. Journal of Botany. 19(1): 121-28

Osbourn, A. C. (1996). Saponins and Plant defence - A soap story. Trends Plant Sci. 1:4-9.

Price, K. R., Johnson, I. T. and Fenwick, G. R. (1987). The chemistry and biological significance of saponins in food and feeding stuffs. Crit. Rev. Food Sci Nutr. 26: 27-133.

Premlatha, D. (1982) Effect of some soil amendment with some green manure on the survival of sclerotia of Corticum Sesaki. India Phytopathology. 35:523-25.

Umar, A., Abdulraham, H. T. and Kokori, M. (2002). Preliminary studies of the efficiencies of the aqueous extracts of leaf and seed kernel of neem for the control of cowpea bruchid Callobruchus maculates. Research Journal of Science. 8 (1_and 2):25-30

Wikipedia-free encyclopedia, (2007), Azadirachtin. Wikipedia Foundation, U.S.A. 4105pp. 